\title{
Penerapan Mobile GIS pada Peta Panduan Jalur Angkutan Umum Berbasis Android dengan Metode Optimasi Rute Ant Colony Optimization
}

\author{
Salmiati $^{1}$, Salama Manjang ${ }^{1}$, Inggrid Nurtanio ${ }^{1}$ \\ ${ }^{1}$ Departemen Teknik Elektro, Fakultas Teknik, Universitas Hasanuddin \\ J1. Poros Malino Km. 6, Bontomarannu, Gowa, Sulawesi Selatan 92171 \\ *Email: salmiatijunaedy@gmail.com
}

\begin{abstract}
Abstrak
Dalam mendukung pengembangan jaringan sistem transportasi cerdas, Mobile GIS menjadi salah satu faktor pendukung, dimana mobile GIS ini dapat menjadi pemandu bagi pengguna transportasi untuk bepergian dengan menggunakan angkot. Oleh karena itu, penelitian ini bertujuan untuk membangun sebuah aplikasi yang berbasis android untuk menentukan jalur angkot yang optimal menuju tujuan yang diinginkan. Melalui penerapan Mobile GIS ini pengguna mendapatkan informasi tentang kode angkot apa saja yang dapat digunakan, jalur alternatif yang mana yang lebih menguntungkan dan jumlah biaya yang harus dibayarkan. Masalah timbul manakala rute yang diinginkan pengguna harus dengan proses transfer rute yang mungkin bisa hanya satu kali transfer, dua kali transfer atau lebih. Dengan demikian untuk optimasi rute yang digunakan adalah metode Ant Colony Optimization. Algoritma Ant Colony Optimization merupakan salah satu jenis algoritma yang meniru prilaku serangga (swarm) yaitu semut. Namun kasus rute angkot ini, untuk mencapai rute optimal dalam metode Ant Colony Optimization ini yang diperhitungkan adalah jarak dan jumlah angkot, dengan asumsi bahwa meskipun rute tersebut berjarak dekat, tetapi kurang angkot yang melalui rute tersebut, maka rute tidak dianggap optimal. Dalam implementasi aplikasi ini membutuhkan waktu akses kurang lebih 1 menit. Hal ini dikarenakan adanya proses pengambilan data dari Google Maps, selain itu juga bergantung pada akses jaringan yang digunakan.
\end{abstract}

\begin{abstract}
This research aimed to formulate an application which was based on android in order to determine the route of the optimun transports with the desired destination. Through the application of a Mobile GIS the users would be able to enquire information about any transport code which he could use, which alternative was more beneficial, and how much cost he would pay. The problem would arise when the desired route by the user should be through the process of transferred route which could be only once transfer, twice transfer or more. Thus, for the optimun used, the route to use was the method of ant colony optimization. The Algorithm of Ant Colony Optimization was one of the algorithm type which imitated the behavior of an insect (swarm), or ant. However, the case of this transport route, in order to reach the optimum route in the method of Ant Colony Optimization, the counted factors were the distance and the number of transports, with assumption that although the route was xlose by, but the transports were not many which ran the route, such route could not be categorized as optimum. In the implementation of this application of this application it needed the time of access less than 1 minute. This was caused by the process of getting the data from the Google Maps besides, this depended on network access used.
\end{abstract}

Kata-Kunci : Mobile GIS, Ant Colony Optimization, GPS, rute.

\section{Pendahuluan}

Sistem transportasi cerdas, berdasarkan sinergi antara teknologi informasi baru untuk simulasi, kontrol real-time, dan jaringan komunikasi merupakan alternatif untuk meningkatkan pengelolaan sumber daya yang tersedia [1]. Perkembangan teknologi smartphone tidak hanya menawarkan fungsi standar dari handphone sebagai alat komunikasi tetapi juga menawarkan kemampuan untuk membantu kegiatan sehari-hari. Dalam mendukung pengembangan jaringan sistem transportsi cerdas, Mobile GIS dapat menjadi salah satu faktor pendukung, dimana Mobile GIS ini dapat memandu pengguna transportasi.

Untuk menjelajah di Kota Makassar ini dapat menggunakan beberapa jenis angkutan darat, salah satunya adalah dengan angkutan umum (angkot). Namun, angkot (pete-pete) yang ada 
dikota Makassar terdapat beberapa rute dengan izin trayek masing-masing. Tentunya bagi orang awan merasa kesulitan jika hendak bepergian seorang diri tanpa adanya pemandu jalan dengan menggunakan angkot. Sedangkan bepergian dengan menggunakan seorang pemandu jalan harus mengeluarkan biaya tambahan. Salah satu solusi yang tepat adalah dengan adanya peta panduan jalan yang bisa dibawa setiap saat dan mudah di gunakan. Maka pada penelitian ini lebih dititik beratkan pada peta angkutan umum dengan memanfaatkan kecanggihan teknologi informasi.

Mobile GIS merupakan integrasi antara tiga teknologi, yaitu perangkat lunak GIS, teknologi Global Positioning System (GPS), dan perangkat alat komunikasi genggam [2]. Teknologi tersebut membuat basis data yang dapat diakses oleh personil di lapangan secara langsung di segala tempat dan waktu. Sistem ini dapat menambah informasi secara real-time ke basis data dan aplikasinya dalam hal kecepatan akses, tampilan, dan penentuan keputusan. Mobile GIS adalah perpaduan dari teknologi GIS, Mobile hardware dengan perangkat lunaknya, Global Positioniong System (GPS) dan komunikasi wireless untuk akses ke internet GIS.

Global Positioning System (GPS) adalah sistem untuk menentukan letak di permukaan bumi dengan bantuan penyelarasan (synchronization) sinyal satelit. Sistem ini menggunakan 24 satelit yang mengirimkan sinyal gelombang mikro ke Bumi. Sinyal ini diterima oleh alat penerima di permukaan, dan digunakan untuk menentukan letak, kecepatan, arah, dan waktu. Sistem yang serupa dengan GPS antara lain GLONASS Rusia, Galileo Uni Eropa, IRNSS India [3].

Google Maps adalah sebuah jasa peta globe virtual gratis dan online disediakan oleh Google. Ia menawarkan peta yang dapat diseret dan gambar satelit untuk seluruh dunia dan baru-baru ini, Bulan, dan juga menawarkan perencana rute dan pencari letak bisnis di U.S., Kanada, Jepang, Hong Kong, Cina, UK, Irlandia (hanya pusat kota) dan beberapa bagian Eropa [4].

Penerapan Mobile GIS, dapat menjadi petunjuk jalan bagi pengguna yang menggunakan angkutan umum sampai tujuan, dimana pengguna mendapatkan informasi tentang kode angkot apa saja yang dapat digunakan, jalur alternatif yang mana yang lebih menguntungkan serta pengguna juga dipandu sampai pada titik persinggahan untuk transfer ke angkot berikutnya apabila itu diperlukan.

Data yang cukup banyak dan kompleks menjadi salah satu persoalan dalam mengembangkan Mobile GIS ini. Namun, yang paling penting adalah bagaimana cara memanipulasi hal tersebut sehingga proses pencarian rute tidak terlalu memakan waktu yang lama sehingga pengguna tetap merasa nyaman menggunakannya. Persoalan lain timbul manakala rute yang diinginkan pengguna harus dengan proses transfer rute dan proses transfer rute ini bisa hanya satu kali transfer, dua kali transfer ataupun lebih. Dengan demikian untuk optimasi rute yang digunakan adalah dengan algoritma Ant Colony Optimization.

Ant Colony Optimization (ACO) termasuk dalam kelompok Swarm Intelligence. yang merupakan salah satu jenis pengembangan paradigma yang digunakan untuk menyelesaikan masalah optimasi dimana inspirasi yang digunakan untuk memecahkan masalah tersebut berasal dari perilaku kumpulan atau kawanan (swarm) serangga [5].

\section{Penelitian Terkait}

Peta panduan ini telah ada dari beberapa peneliti sebelumnya salah satunya dengan menggunakan metode Best-Path Planning di kota Surabaya. Namun, hasil dari penelitian ini, memperlihatkan bahwa dengan kompleksnya rute transportasi umum yang ada dan banyaknya data tempat yang dilewati, sehingga penggunaan matriks transisi membutuhkan waktu yang lama pada proses load data yaitu 1 menit 15 detik, sedangkan untuk pencarian rute dua kali transfer, membutuhkan waktu rata-rata 49,55 detik [6].

Penelitian lain dengan menggunakan algoritma Particle Swarn Optimization memberikan kesimpulan bahwa Pencarian jalur terpendek dengan metode algoritma Particle Swarm Optimization (PSO) tergantung dari parameter-parameter yang dimasukkan. 
Banyaknya parameter inputan seperti iterasi dan partikel akan sangat menentukan kesuksesan pencarian jalur terpendek. Semakin besar parameter yang diberikan,maka waktu yang dibutuhkan dalam memproses akan semakin lama. Algoritma PSO ini masih memiliki titik kelemahan, system pencarian random membuat hasil pencarian belum tentu mendapatkan hasil yang benar-benar optimum [7].

\section{Perancangan Sistem}

\subsection{Desain Sistem}

Desain sistem dapat digambarkan bahwa begitu pengguna menggunakan menentukan lokasi, maka sistem langsung mengkoordinasikan ke GPS, sehingga menghasilkan titik koordinat posisi awal dan posisi tujuan. Selanjutnya sistem akan menghitung jarak dengan melalui titik persinggahan dimana angkot dapat bersinggungan. Dari hasil jarak perhitungan tersebut kemudian diterapkan metode optimasi rute Ant Colony Optimization (ACO) untuk memilih 2 rute terdekat, dan kemudian menampilkannya. Setelah pengguna memilih salah satu rute terdekat, maka pada mobile pengguna tampil peta untuk menuju ke posisi tujuan dengan melalui titik persinggahan.

Dari rancangan sistem yang dipaparkan sebelumnya dapat dianalisa bahwa sistem yang akan dibangun seperti arsitektur aplikasi pada Gambar 1 berikut:

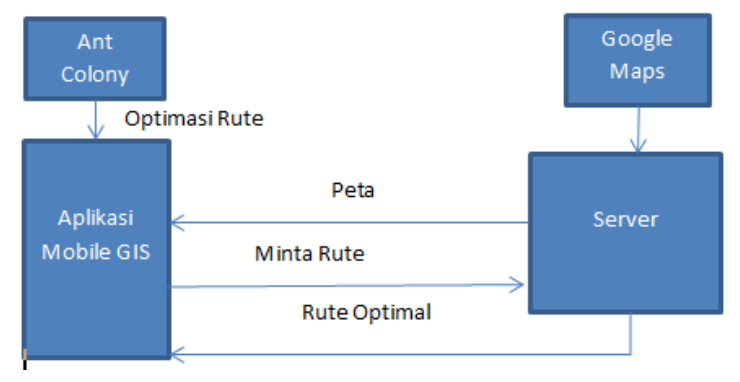

Gambar 1. Arsitektur Aplikasi

Adapun diagram yang dibutuhkan dalam mendesain sistem yaitu usecase diagram pada Gambar 2, dan squence diagram ada Gambar 3, Gambar 4, Gambar 5 dan Gambar 6 berikut :

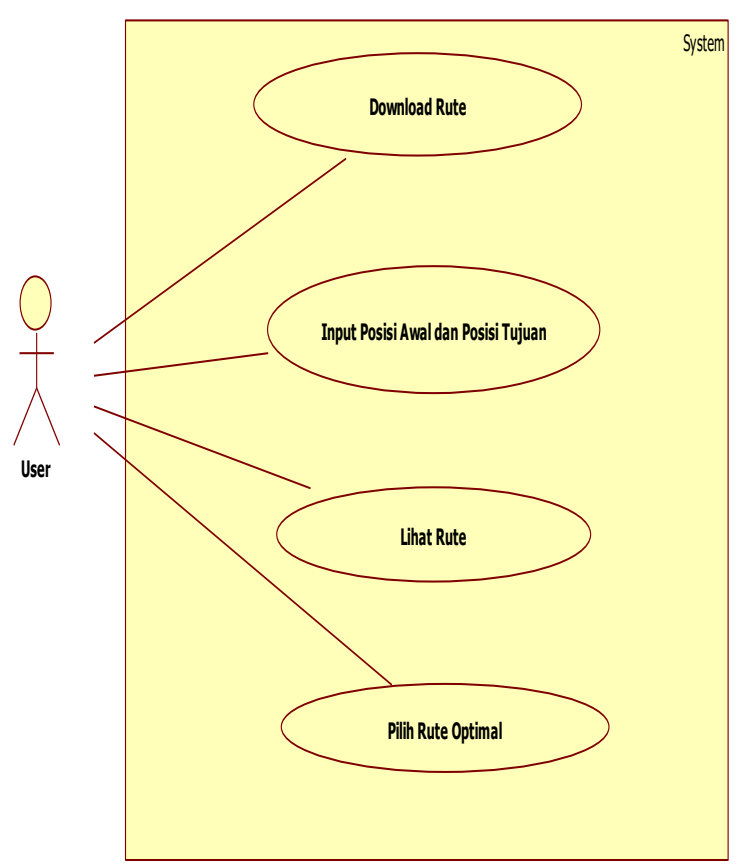

Gambar 2. Use Case Diagram

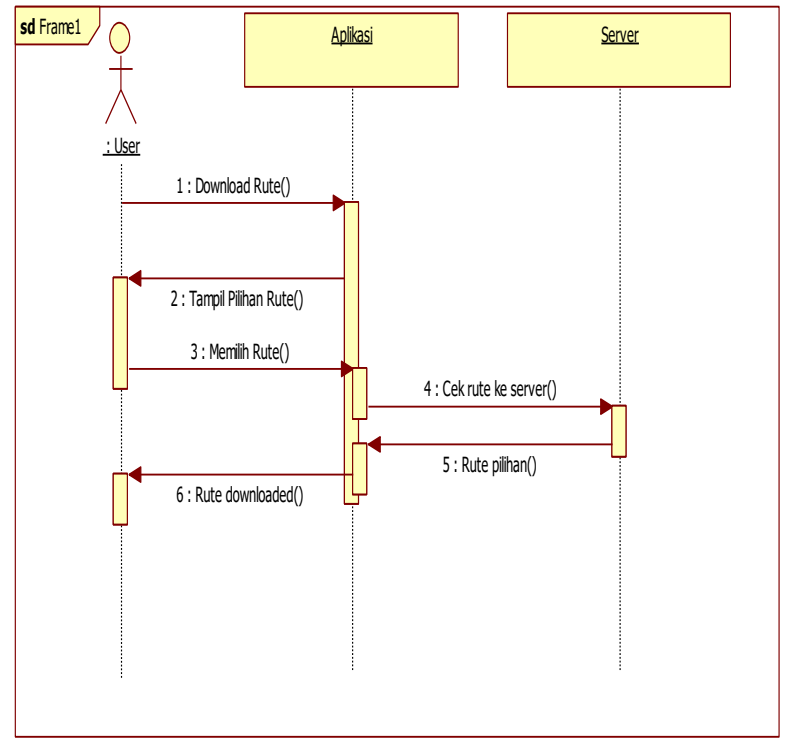

Gambar 3. Squence Diagram download rute 


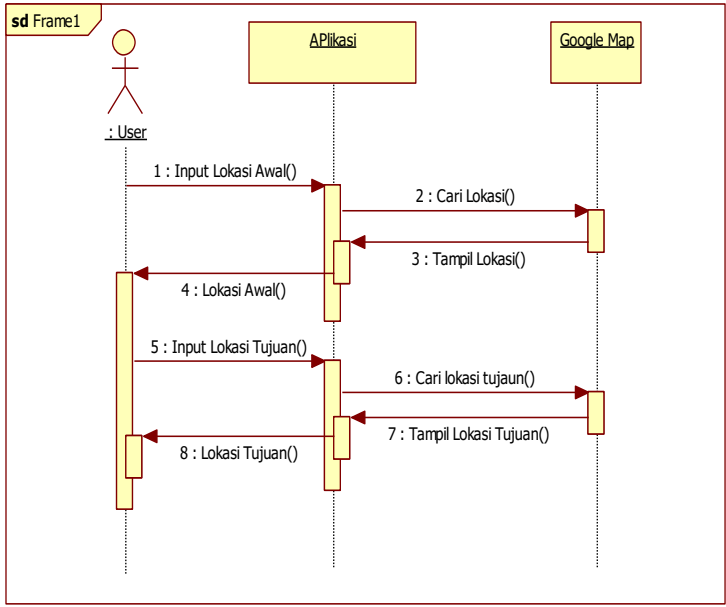

Gambar 4. Squence diagram untuk input lokasi

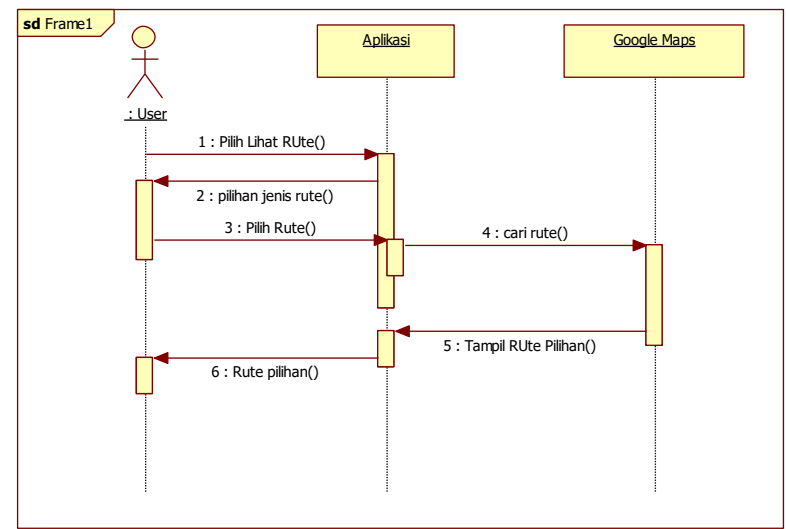

Gambar 5. Squence diagram untuk lihat rute

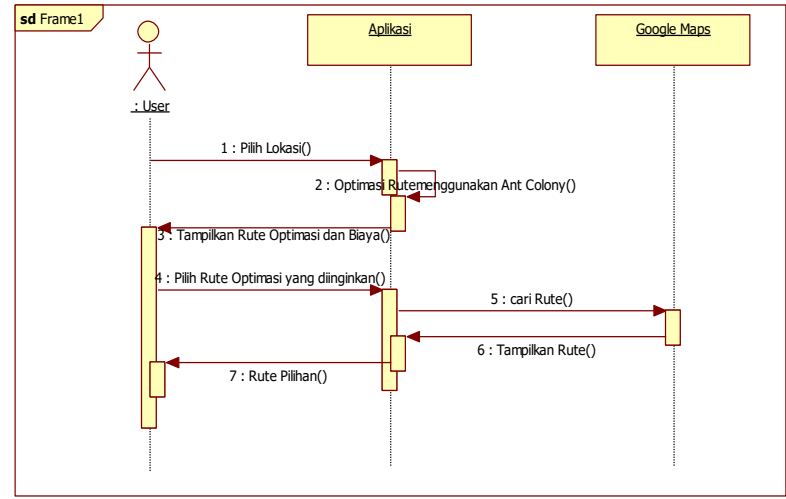

Gambar 6. Squence diagram untuk pilih rute optimal

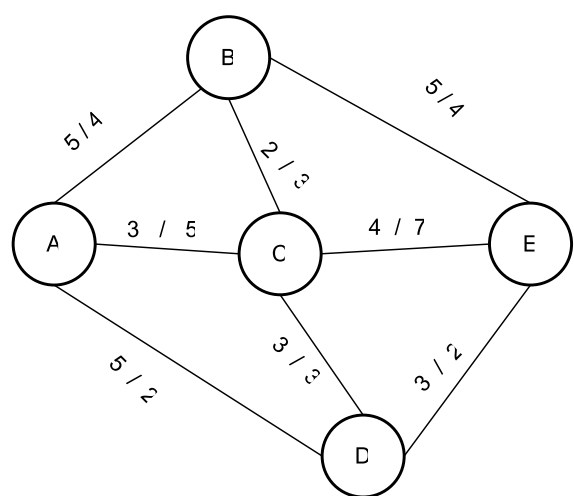

Gambar 7: Graph Berbobot

Untuk mencari rute optimal dari titik A menuju titik E terdapat beberapa lintasan (path), adapun path yang dilalui dapat dilihat pada Tabel 1 berikut :

Tabel 1 : Tabel daftar rute alternatif

\begin{tabular}{cc}
\hline Rute & Path yang dilalui \\
\hline 1 & AB-BE \\
\hline 2 & AC-CE \\
\hline 3 & AD-DE \\
\hline 4 & AC-CB-BE \\
\hline 5 & AB-BC-CE \\
\hline 6 & AC-CD-DE \\
\hline 7 & AD-DC-CE \\
\hline 8 & AB-BC-CD-DE \\
\hline 9 & AD-DC-CB-BE \\
\hline
\end{tabular}

Pemilihan rute dari simpul A ke simpul E dengan formula:

$$
P_{A E}=\frac{\left(\tau_{A E}^{\alpha}\right)\left(\eta_{A E}^{\beta}\right)}{\sum\left(\tau_{A E}\right)\left(\eta_{A E}\right)}
$$

Hasil dari perhitungan untuk setiap lintasan (path) dapat dilihat pada Tabel 2 berikut :

\subsection{Metode optimasi koloni semut}

Dalam penentuan optimasi koloni semut, dibutuhkan beberapa parameter dan data jalan serta titik asal dan titik tujuan sehingga sistem dapat memberikan hasil pencarian jalur yang paling optimal. Sebagai perumpamaan seperti tampak pada Gambar 7 : 
Tabel 2. Tabel hasil perhitungan nilai p setiap Path

\begin{tabular}{|c|c|c|c|c|c|c|c|c|}
\hline Path & $\begin{array}{c}\text { Jarak } \\
(\delta) \\
\end{array}$ & $\begin{array}{c}\text { Jumlah } \\
(\lambda)\end{array}$ & $\eta=1 / \delta$ & $\lambda^{\alpha}$ & $\eta^{\beta}$ & $\lambda^{\alpha \cdot} \eta^{\beta}$ & Nilai $\mathbf{P}$ & $\begin{array}{c}\mathbf{P} \\
\text { Terbaik } \\
\end{array}$ \\
\hline $\mathrm{AB}$ & 4 & 5 & 0.25 & 1.37973 & 0.87055 & 1.20112 & 0.35170 & \multirow{3}{*}{0.36196} \\
\hline $\mathrm{AC}$ & 3 & 5 & 0.33 & 1.37973 & 0.89596 & 1.23618 & 0.36196 & \\
\hline $\mathrm{AD}$ & 5 & 2 & 0.20 & 1.14870 & 0.85134 & 0.97793 & 0.28634 & \\
\hline $\mathrm{BC}$ & 2 & 3 & 0.50 & 1.24573 & 0.93303 & 1.16231 & 0.50852 & \multirow{2}{*}{0.50852} \\
\hline $\mathrm{BE}$ & 5 & 4 & 0.20 & 1.31951 & 0.85134 & 1.12335 & 0.49148 & \\
\hline $\mathrm{CB}$ & 2 & 4 & 0.50 & 1.31951 & 0.93303 & 1.23114 & 0.33897 & \multirow{3}{*}{0.35373} \\
\hline $\mathrm{CD}$ & 3 & 3 & 0.33 & 1.24573 & 0.89596 & 1.116212 & 0.30730 & \\
\hline $\mathrm{CE}$ & 4 & 7 & 0.25 & 1.47577 & 0.87055 & 1.28474 & 0.35373 & \\
\hline $\mathrm{DC}$ & 3 & 4 & 0.33 & 1.31951 & 0.89596 & 1.18222 & 0.53460 & \multirow{2}{*}{0.53460} \\
\hline $\mathrm{DE}$ & 3 & 2 & 0.33 & 1.14870 & 0.89596 & 1.02919 & 0.46540 & \\
\hline
\end{tabular}

Hasil dari perhitungan diatas diketahui bahwa path terbaik dari simpul A yaitu path AC sebagaimana yang tampil pada Gambar 8 berikut:
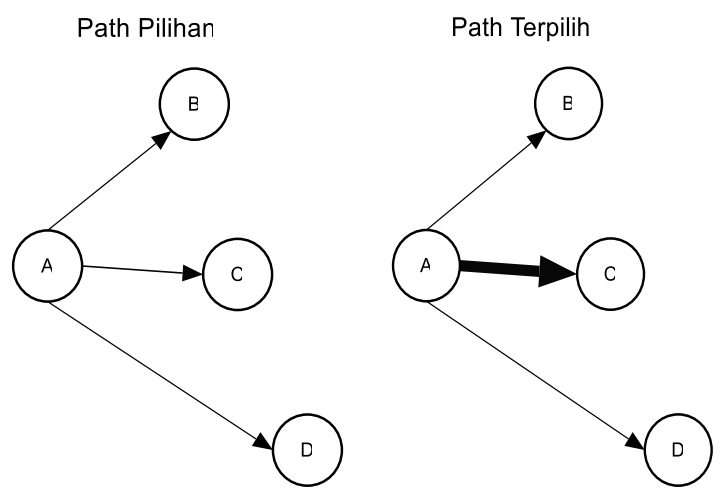

Gambar 8. Path terbaik dari simpul A

Sedangkan untuk path terbaik dari simpul C adalah CE sebagaimana pada Gambar 9 berikut:
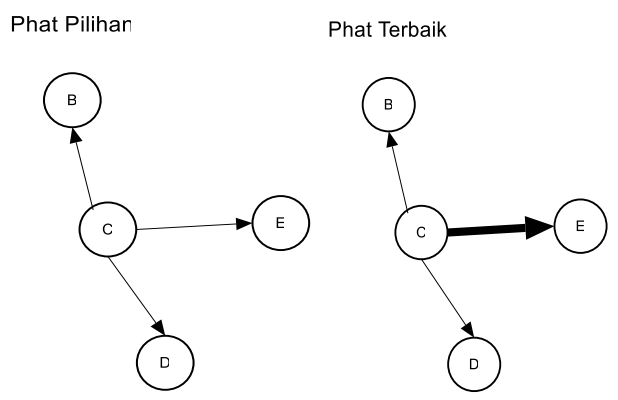

Gambar 9. Path terbaik
Sehingga didapatkan path optimal dari A ke E adalah ACE seperti pada Gambar 10 :

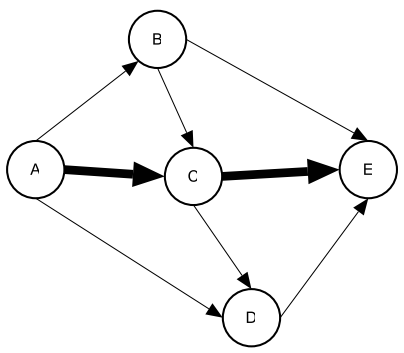

Gambar 10. Path terbaik dari A ke E

\section{Analisis dan Pengujian Sistem}

\subsection{Analisis Algoritma}

Untuk kasus dalam penelitian ini, selain parameter jarak yang diperhitungkan adapula banyaknya angkot yang melewati rute tersebut, dengan anggapan bahwa semakin banyak jumlah angkot yang melewati rute itu, semakin besar peluang untuk mendapatkan angkot lebih cepat. Sehingga hasil dari optimasi rute yang dihasilkan lebih dominan ke rute yang ramai dilalui angkot. Seperti pada contoh kasus berikut ini :

Seorang pengguna hendak berangkat dari Kompleks Vila Mutiara Jl. Tol menuju Kampus STMIK Dipanegara yang berada di jalan Perintis Kemerdekaan KM. 9. Dimana rute dari jalan Tol menuju kampus STMIK ini tidak ada angkot yang langsung, dan harus menggunakan beberapa angkot untuk mencapai titik tujuan 
tersebut. Rute perjalanan dapat digambarkan pada Gambar 11 berikut :

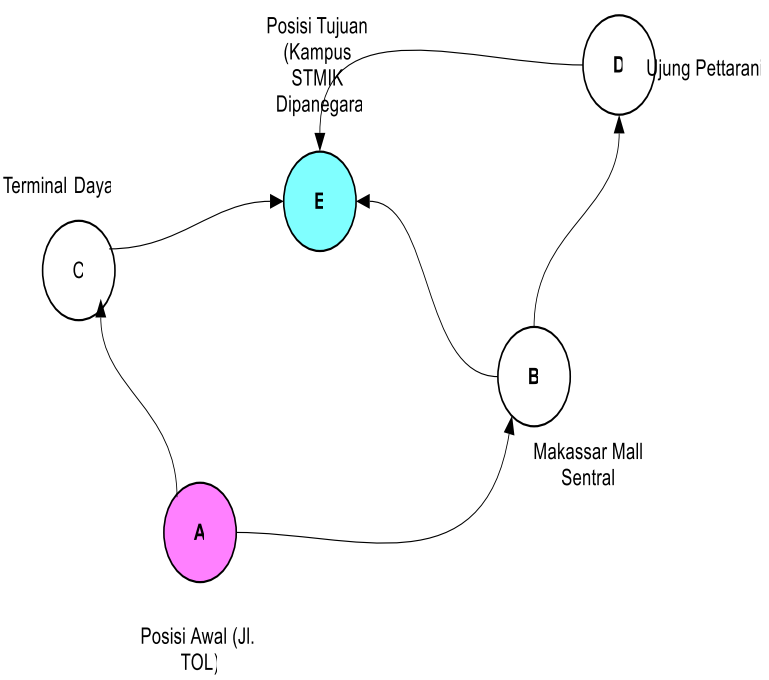

Gambar 11. Lintasan rute yang dapat dilalui dari Tol menuju kampus STMIK Dipanegara

Dari Gambar 11 tersebut dapat dilihat bahwa untuk menuju kampus Stmik Dipanegara dari posisi awal di jalan tol adalah :

- Rute dari Posisi awal menuju Terminal Daya kemudian lanjut ke kampus STMIK Dipanegara.

- Rute dari Posisi awal menuju Makassar Mall sentral kemudian lanjut menuju ke kampus STMIK Dipanegara.

- Rute dari Posisi Awal menuju Makassar Mall sentral, kemudian lanjut menuju ke ujung Pettarani kemudian lanjut ke kampus Unhas.

Dari keterangan yang telah dijelaskan, disimpulkan bahwa ada beberapa rute yang dapat dilalui untuk menempuh titik tujuan yang telah ditentukan. Adapun bobot keterangn untuk lintasan setiap rute dapat dilihat pada Tabel 3 berikut :

Table 3. Jarak dan Jumlah angkot setiap lintasan

\begin{tabular}{cccc}
\hline Lintasan & $\begin{array}{c}\text { Jarak } \\
(\mathbf{K M}) \boldsymbol{\delta}\end{array}$ & $\begin{array}{c}\text { Jumlah } \\
\text { Angkot } \\
(\boldsymbol{\lambda})\end{array}$ & $\boldsymbol{\eta}=(\mathbf{1} / \boldsymbol{\delta})$ \\
\hline $\mathrm{AB}$ & 11.3 & 201 & 0.08850 \\
$\mathrm{AC}$ & 9 & 20 & 0.11111 \\
$\mathrm{BD}$ & 6 & 188 & 0.16667 \\
$\mathrm{BE}$ & 8.3 & 694 & 0.12048 \\
$\mathrm{CE}$ & 4.9 & 694 & 0.20408 \\
$\mathrm{DE}$ & & 127 & 0.09174 \\
\hline
\end{tabular}

Sesuai dengan ketentuan dalam algoritma optimasi koloni semut bahwa untuk menetapkan nilai pengendali intensitas visibilitas $(\beta)$ dan nilai pengendali pheromon $(\alpha)$ harus $\geq 0$ dan nilai tetapan penguapan peromon $(\rho)$ harus $>0$ dan $<$ 1. Jika nilai dari intensitas visibilitas $(\beta)$ ditetapkan 0.5 dan nilai pengendali pheromon $(\alpha)$ ditetapkan 1, diterapkan dalam formula berikut:

$$
P_{i j}=\frac{\left(\tau_{i j}^{\alpha}\right)\left(\eta_{i j}^{\beta}\right)}{\sum\left(\tau_{i j}\right)\left(\eta_{i j}\right)}
$$

Solusi rute terbaik antara lintasan $A B$ dan lintasan AC

\section{Path AB :}

$$
\begin{aligned}
P_{A B} & =\frac{\left(\tau_{A B}^{1}\right)\left(\eta_{A B}^{\beta}\right)}{\left(\tau_{A B}\right)\left(\eta_{A B}\right)+\left(\tau_{A C}\right)\left(\eta_{A C}\right)} \\
P_{A B} & =\frac{\left(201^{0.5}\right)\left(0.0885^{1}\right)}{(201) \cdot(0.0885)+(20) \cdot(0.1111)} \\
P_{A B} & =\frac{(14.1774)(0.0885)}{17.7885+2.222} \\
P_{A B} & =\frac{1.2546999}{20.0105} \\
P_{A B} & =\mathbf{0 . 6 2 7 0 2}
\end{aligned}
$$

\section{Path AC:}

$P_{A C}=\frac{\left(\tau_{A C}^{1}\right)\left(\eta_{A C}^{\beta}\right)}{\left(\tau_{A B}\right)\left(\eta_{A B}\right)+\left(\tau_{A C}\right)\left(\eta_{A C}\right)}$

$P_{A C}=\frac{\left(20^{0.5}\right)\left(0.1111^{1}\right)}{(201) \cdot(0.0885)+(20) \cdot(0.1111)}$

$P_{A C}=\frac{(4.4721)(0.1111)}{17.7885+2.222}$

$P_{A C}=\frac{0.4969}{20.0105}$

$P_{A C}=0.02483$

Rute optimal antara lintasan $\mathrm{AB}$ dan lintasan $\mathrm{AC}$ adalah Lintasan $\mathrm{AB}=0.62702$.

Untuk mencari rute berikutnya maka yang harus dilihat adalah lintasan yang berawal dari titik B, yaitu lintasa BD dan lintasan BE dengan perhitungan :

\section{Path BD}

$P_{B D}=\frac{\left(\tau_{B D}^{1}\right)\left(\eta_{B D}^{\beta}\right)}{\left(\tau_{B D}\right)\left(\eta_{B D}\right)+\left(\tau_{B E}\right)\left(\eta_{B E}\right)}$ 


$$
\begin{aligned}
P_{B D} & =\frac{\left(188^{0.5}\right)\left(0.1667^{1}\right)}{(188) \cdot(0.1667)+(694) \cdot(0.1205)} \\
P_{B D} & =\frac{(13.7113)(0.1667)}{31.3396+83.627} \\
P_{B D} & =\frac{2.2857}{114.9666} \\
\boldsymbol{P}_{B D} & =\mathbf{0 . 0 1 9 9}
\end{aligned}
$$

\section{Path BE}

$$
P_{B E}=\frac{\left(\tau_{B E}^{1}\right)\left(\eta_{B E}^{\beta}\right)}{\left(\tau_{B D}\right)\left(\eta_{B D}\right)+\left(\tau_{B E}\right)\left(\eta_{B E}\right)}
$$

$$
\begin{aligned}
P_{B E} & =\frac{\left(694^{0.5}\right)\left(0.1205^{1}\right)}{(188) \cdot(0.1667)+(694) \cdot(0.1205)} \\
P_{B E} & =\frac{(26.3439)(0.1205)}{31.3396+83.627} \\
P_{B E} & =\frac{3.1744}{114.9666} \\
\boldsymbol{P}_{B E} & =\mathbf{0 . 0 2 7 6}
\end{aligned}
$$

Hasil dari perhitungan diatas dapat dilihat pada Tabel 4 berikut :

Tabel 4. Tabel analisis jalur optimal dengan koloni semut

\begin{tabular}{ccccccccc}
\hline Path & $\boldsymbol{\delta}$ & $\boldsymbol{\lambda}$ & $\boldsymbol{\eta}=\mathbf{1} / \boldsymbol{\delta}$ & $\boldsymbol{\lambda}^{\alpha}$ & $\eta^{\beta}$ & $\boldsymbol{\lambda}^{\alpha} \cdot \eta^{\beta}$ & Nilai P & P Terbaik \\
\hline AB & 11.3 & 201 & 0.0885 & 14.1775 & 0.0885 & 1.25464 & 0.7163 & \multirow{2}{*}{0.7163} \\
AC & 9 & 20 & 0.1111 & 4.47214 & 0.1111 & 0.49690 & 0.2837 & \\
\hline BD & 6 & 188 & 0.1667 & 13.7113 & 0.1667 & 2.28522 & 0.3837 & \multirow{2}{*}{0.5329} \\
BE & 8.6 & 694 & 0.1205 & 26.3438 & 0.1205 & 3.17396 & 0.5329 & \\
\hline
\end{tabular}

Dari hasil analisa pada Tabel 4 dapat disimpulkan bahwa rute yang optimal dari jalan Tol menuju kampus STMIK adalah rute yang melalui lintasan dari A ke B kemudian lanjut dari lintasan B ke E. rute yang dimaksud adalah Rute dari jalan tol menuju sentral dengan kode angkot G (Tol), dengan biaya Rp. 7000,- kemudian lanjut rute dari sentral ke smtik dengan kode angkot D (Daya) dengan biaya Rp. 5000,-. Sebagaimana yang ditampilkan pada aplikasi hasil pencarian rute pada aplikasi seperti pada Gambar 12 berikut:

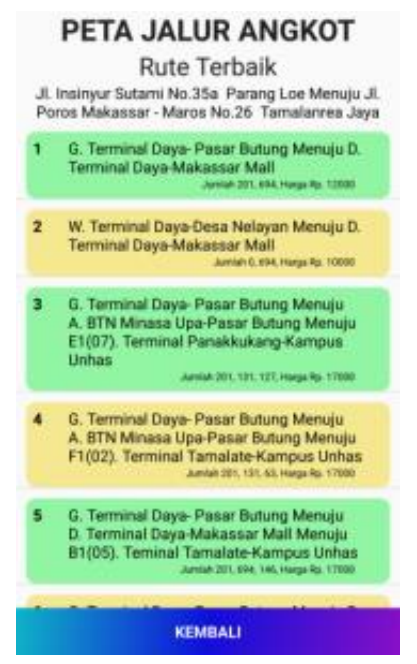

Gambar 12. Tampilan hasil pencarian rute optimal

\subsection{Implementasi Sistem}

Implementasi Sistem merupakan prosres yang dilakukan untuk menyelesaikan konsep desain yang ada pada desain sistem. Hasil akhir dari sistem yang telah dirancang dapat dilihat pada Gambar 13:

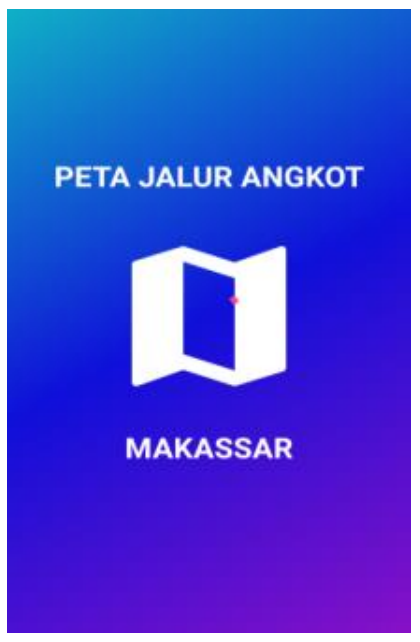

Gambar 13. Tampilan Splash Screen 


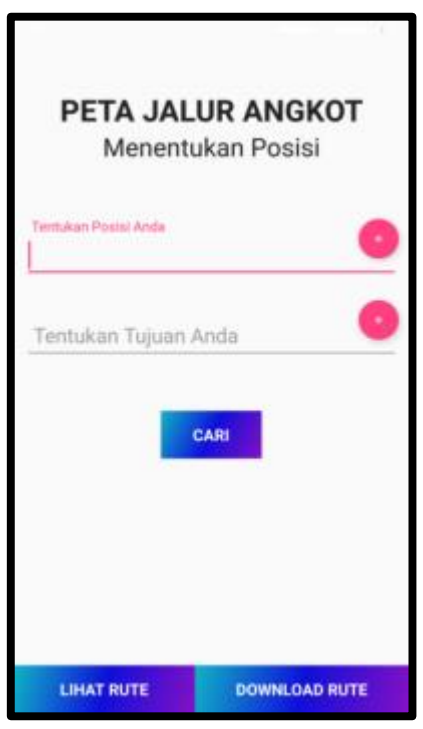

Gambar 14. Tampilan menu utama

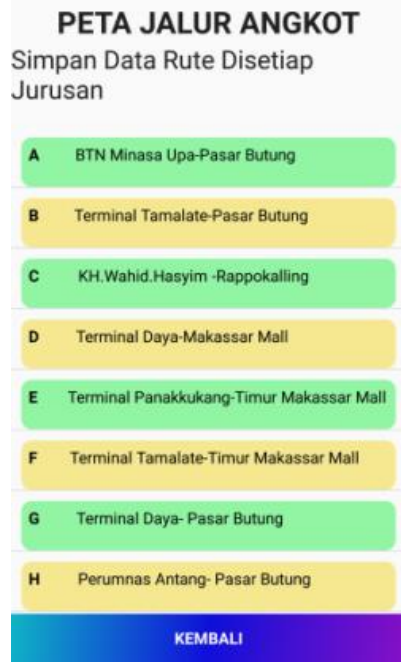

Gambar 15. Tampilan download rute

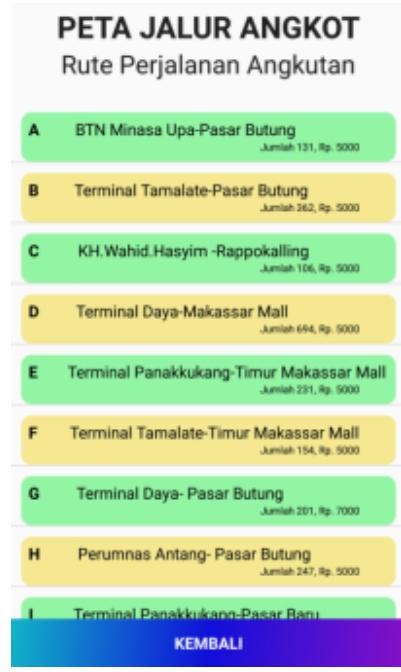

Gambar 16. Tampilan daftar rute

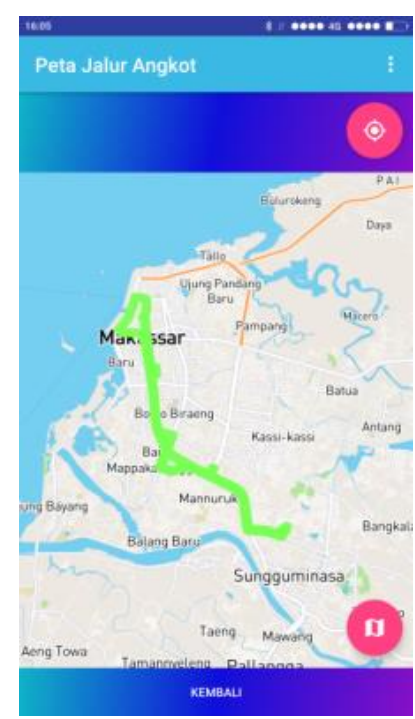

Gambar 17. Tampilan lihat rute pada peta

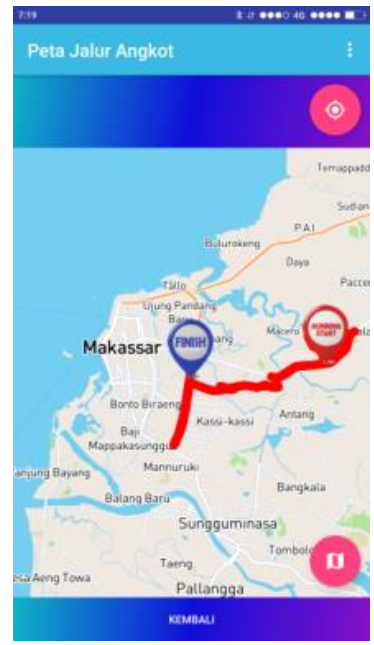

Gambar 18. Tampilan rute pada peta

\subsection{Pengujian Sistem}

Pengujian sistem dilakukan dengan 2 metode pengujian yaitu pengujian BlackBox dan Pengujian dengan angket (koesioner). Pengujian blackbox dilakukan melalui implementasi sistem yang telah dilakukan sebelumnya menunjukkan bahwa aplikasi dapat menampilkan output ruterute sesuai dengan perintah masukan. Sedangkan pengujian dengan angket yaitu dengan cara membagi koesioner kepada sejumlah pengguna angkutan umum dengan pertanyaan-pertanyaan yang berkaitan dengan kepentingan pengguna. 


\section{Kesimpulan}

Penerapan Mobile GIS ini diharapkan dapat membantu memandu pengguna terutama bagi pendatang di kota Makassar dalam perjalanannya dengan menggunakan angkutan kota tanpa harus bertanya-tanya dan takut kesasar. Pada penerapan Mobile GIS ini pula, pengguna dapat langsung mengetahui apabila angkutan yang ditumpanginya keluar dari jalur yang seharusnya.

Dari penelitian jalur optimal menggunakan algoritma koloni semut, ditarik sebuah kesimpulan bahwa Proses pengambilan data dari google maps, mengakibatkan jalannya aplikasi agak lambat dan harus menunggu untuk beberapa saat. Data jalan pada peta google belum sepenuhnya dapat sesuai dengan fakta sehingga penggunaanya pada aplikasi ini tidak sepenuhnya menampilkan output yang sesuai.

Pengaruh jumlah angkot dapat mempengaruhi proses pencarian jalur optimasi, semakin banyak angkot yang melewati jalur tersebut maka semakin besar kemungkinan jadi jalur optimal.

Dalam proses pencarian rute, penentuan posisi sebaiknya dilakukan dengan membuka peta kemudian mengatur posisi pada jalan atau lokasi yang dituju, disebabkan karena pada peta google masih terdapat sejumlah jalan yang belum terdeteksi oleh google maps.

\section{Referensi :}

[1] Aamir Khan, Aasim Khurshid, Muhammad Farhan, Muhammad Harris. "Agent Based Intelligent Transportation System ". 2012.

[2] Guntara, "Mengenal Teknologi Mobile GIS di Era Globalisasi”, diunduh [15 September 2014] melalui http://www.guntara.com/2014/01/mobile-gismerupakan-integrasi-antara.html

[3] Wikipedia, "Sistem Pemosisi Global", diunduh [15 September 2014] melalui https://id.wikipedia.org/wiki/Sistem_Pemosisi_Global

[4] Andrafarm, "Google Maps", diunduh [15 September 2014] melalui melalui http://maps.andrafarm.com/id1/28872783/Maps_99952_maps-andrafarm.html

[5] Budi Santosa, Phd. "Ant Colony Optimization”. 2012.

[6] Rizky Pratiwi, Ary Mazharudin Shiddiqi, S.Kom, M.Comp. Sc, Baskoro Adi Pratomo, S.Kom, M.Kom. 2012. "Aplikasi Mobile Pencarian Rute Transportasi Umum dengan Algoritma Best-Path Planning pada Platform Android. Seminar Tugas Akhir".

[7] Alkis Fuady M, Arna Farisa, S.Kom.M.Kom, Ira Prasetyaningrum, S.Si, MT. "Aplikasi GIS Berbasis J2ME Pencarian Jalur Terpendek Menggunakan Algoritma Particle Swarm Optimization (PSO) Di Kabupaten Bangkalan". 